\title{
SOUNDING THE DEPTHS OF PROVIDENCE: MINERAL (RE)GENERATION AND HUMAN-ENVIRONMENT INTERACTION IN THE EARLY MODERN PERIOD
}

\author{
FRANCESCO LUZZINI \\ Max Planck Institute for the History of Science, Department I \\ Boltzmannstraße 22 - 14195 Berlin, Germany \\ fluzzini@mpiwg-berlin.mpg.de / francesco_luzzini@yahoo.com
}

\begin{abstract}

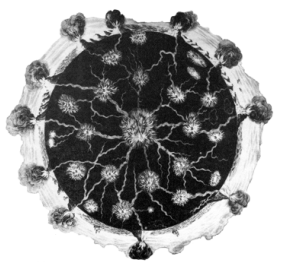

Earth Sciences History

Vol. 39, No. 2, 2020 pp. $389-408$

The genesis and growth of minerals, as well as the existence in ore veins of such organic features as 'seeds', 'matrices', and 'nourishment', remained central and recurrent issues for natural philosophers, technicians, alchemists and practitioners throughout early modern Europe. By providing an overview of the main themes, voices, and concurrent factors (scientific, philosophical, economic, political, cultural, geographical, religious, social) that shaped the evolution of such long-standing dispute, this essay attempts a preliminary analysis of how the early modern understanding of mineral generation influenced our perception of natural exploitability, renewability and exhaustibility - and, more generally, the development of the Earth sciences and the emergence of humans as geological and environmental agents. These issues are also the subject of a new interdisciplinary project which is introduced in the final part of the article and which, hopefully, will be implemented in the next years with the aim to disclose new insights into our comprehension of the human-environment system.
\end{abstract}

Keywords: Early modern mining, natural philosophy, mineralogy, environmental history, natural resources

doi: $10.17704 / 1944-6187-39.2 .389$

\section{TERMINOLOGICAL CLUES}

This paper was inspired by a conversation I had in early 2018 with Paolo Ferretti, a mineralogist working at the Museum of Sciences in Trento (northeastern Italy). In addition to being a fine scientist and a museum curator, ${ }^{1}$ Paolo is also a passionate expert in mining history, and this was enough to persuade me that I could pester him with all sorts of questions about mining terminologies and traditions in Renaissance and early modern Italy. One day, while I was boasting to him how interested I was in the early modern debate on mineral generation and regeneration, and on the analogies and terminologies related to this issue, he smiled and pointed out that — still nowadays-Italian miners very often use the expression coltivare la miniera (literally, 'cultivating the mine') when referring to mine exploitation.

Paolo's comment made me aware of my ignorance, and - in addition to the educational effect - it aroused my curiosity. I was charmed by the vestigial appearance of this saying and of several other technical and more or less colloquial expressions (such as 'mother lode', 'fertile ore', 'nourishment', 'seed', 'matrix', etc.) that are still popular among miners. But, I wonder, are these expressions merely vestigial after all? Or, is their persistence through the centuries something more than an accident or a simple residual concept in an otherwise 'evolved' description of the mineral world?

Perhaps, such 'terminological longevity' hints at something still capable of influencing the way humans perceive natural resources and, more broadly, the environment: something rooted in

Recently, Paolo Ferretti (together with Francesco Demartin, Italo Campostrini, and Ivano Rocchetti) discovered and described a new mineral species, fiemmeite $\mathrm{Cu}_{2}\left(\mathrm{C}_{2} \mathrm{O} 4\right)(\mathrm{OH})_{2} \cdot 2 \mathrm{H}_{2} \mathrm{O}-$ a copper oxalate found in the Dolomite Mountains in Val di Fiemme, northeastern Italy. This research is now published in Demartin et al. 2018. 


\section{SOUNDING THE DEPTHS OF PROVIDENCE}

the Renaissance, or even earlier. If so, could it be that the words 'cultivating the mine' (together with other expressions and with their various equivalents in other languages) betray the presence of unexplored and widespread patterns in the way our perception of natural exploitability and renewability developed?

\section{KNOWLEDGES AND CONTEXTS}

It is the general opinion, not onely of the vulgar, but also of most of the mine-men that I have conversed withal, (which have been no small number) that metals do not grow in the Earth, but were all at once created of God; and so have no seminary principle to propagate themselves by. Which foolish conceit the most part of learned men have rejected '. ..'; and therefore it is needless to waste time in the confutation thereof.

Now though the whole stream of mystical authors, or adeptists, have asserted the generation and growth of them; yet have they rather left it as a principle to be granted, and believed of their disciples, or handled it so darkly, that few have been able thorowly to understand it. And therefore (as a point most material and necessary) we shall labour as much as in us lies, to make it clear, both by reasons, and observations from credible authors (Webster 1671, p. 40).

This quote from the Metallographia, an encyclopedic treatise on minerals and metals published in 1671 by the English scholar John Webster $(1610-1682)^{2}$ is, in my view, an exemplary recapitulation of how the early modern use of organic analogies to explain the growth of ore veins was frequent, problematic, and frustratingly elusive in its countless roots, forms, and implications. In fact, although the organic analogy ${ }^{3}$ was quite popular in the mining industry and natural philosophy alike (and both in Europe and the Islamic world), it is also true that many "authors of credible veracity" (Webster 1671, p. 43) were far from clear-let alone unanimousin describing how this analogy worked, and they often struggled to make it compatible with different research methods, geological and geographical contexts, and observations; to the point that the Spanish cleric Alvaro Alonso Barba (1569-1661) voiced a common feeling when he supposed that "the Author of Nature" seemed to "have created" ore veins "in that obscurity, and depth on purpose to hide their causes, and to give check to the ambition of man" (Barba 1729, p. 29). ${ }^{4}$

Despite all the hurdles and the confusion, however, the conceptual advantages of the organic analogy were all but negligible and went beyond the mere scope of natural philosophy. For, not only did this commonly held view allow the explanation of a number of apparent similarities between minerals and living organisms, but it also provided the many who were bound to spend most of their lives in the bowels of the Earth with a reliable theoretical framework to rationalize and contextualize the underground presence of minerals and metals. In doing so, this interpretive model (which was the result of a diverse and entangled array of philosophical and alchemical, as well as religious and practical, traditions) gave a significant contribution to the notion of predictability of mineral resources; and this concept, in turn, was crucially linked to the economic, social, and political interests and hopes which drove the explosive scientific and

2 On Webster, who was a follower of Boyle's corpuscular theory, see Alfonso-Goldfarb and Ferraz 2013, p. 26; Clericuzio 1996; Debus 1977, pp. 93-400, 402-409, 457-458, 514-517; Hirai and Yoshimoto 2005, p. 472.

As suggested by an anonymous reviewer to this paper, the use of the word 'organic' with reference to "a time at which the modern dichotomy of organic vs. inorganic does not yet seem to have existed" (at least not in its modern form) is potentially problematic, since by "using such terms '. . .' we come close to introducing an anachronism" and we "apply the term retrospectively." I am grateful for this clarification. In fact, I believe it necessary to point out that the term 'organic analogy' is used here with reference to the various early modern theories which emphasized the similarities between mineral generation and vegetative growth, whereas this term is not meant to suggest that a modern concept of organic/inorganic dichotomy existed before the eighteenth century.

No es maravilla, que acerca de la materia de que se engendran los metales, aya avido tanta diversidad de opiniones entre personas que puedan autorizarlas; pues parece, que con particular providencia, quiso ocultarla con ellos el Autor de la Naturaleza en la obscura profundidad en que los cria, y dureza de peñas en que los encierra, para poner algun estorvo à la ambicion humana. (The English translation of the passage comes from Barba 1674). 
technological growth of the mining industry during the early modern period - and which made the miserable working conditions and the countless dangers of mining activity more tolerable. ${ }^{5}$

As historians have pointed out, ${ }^{6}$ even the existence in ore veins of a regenerative power was a very popular notion. According to a number of early modern authors from different contexts such as Georgius Agricola (1494-1555), Andrea Cesalpino (1519-1603), Robert Boyle (16271691), Gabriele Falloppio (1523-1562), Johann Gerhard (1582-1637), Johann Mathesius (15041565), Bernard Palissy (1510-1589), Paracelsus (1493-1541), Gabriel Plattes (1600-1644), Johann Joachim Becher (1635-1682), Thomas Sherley (1638-1678), Antonio Vallisneri (16611730), and the already mentioned Alvaro Alonso Barba and John Webster, it was possible for mines - or for certain kinds of mines, at least - to replenish themselves just a few years after being exploited. ${ }^{7}$ Typically, these claims were supported by plenty of authoritative references and by some well-attested, and often overused, examples (Agricola 1546; Boyle 1674, 1676; Cesalpino 1596; Falloppio 1564; Gerhard 1643; Webster 1671; Sherley 1672). ${ }^{8}$ Among the most renowned cases were the iron mines on Elba Island in the Tyrrhenian Sea (west of the Tuscan coast), whose lodes were famous for regenerating "in the space of a hundred years" and whichstill in the eighteenth century-were profitably exploited on behalf of the Dukes of Tuscany (Falloppio 1564, p. 16v). ${ }^{9}$ Similar phenomena were said to have occurred in central Europe in a well-known site close to the Silesian city of Sagan (now part of Żagan County, in western Poland), where the miners dug up "iron in the fields by sinking ditches two foot deep; and digging between the space of ten years the ditches" were "digged again for iron since produced" (Webster 1671, p. 55).

Acknowledging that ore veins were capable of regeneration did not mean that there was agreement on the natural processes and compositional principles responsible for such mysterious phenomena. Thus, this issue became the subject of a discussion where theories and experiences intertwined in countless ways, producing heterogeneous and more or less interrelated explanations. Doubt became a quite common feeling among the debaters, their ideas being frequently subject to ambiguities and fluctuations. This occurred especially when savants, technicians, and practitioners shared their experiences in caves, mines, and in laboratories. It was here that the theoretical frameworks of alchemists, physicians, natural philosophers, and clergymen intermingled (and sometimes clashed) with the practical knowledge of miners, mining officials, and engineers whose beliefs on this subject were equally flexible: and even more so given the geographical, geological, social, religious, and political differences between mining contexts across Europe.

\footnotetext{
$5 \quad$ For an in-depth study of this crucial issue (especially with respect to the role played by economic, cultural, and social factors in the evolution of early modern mining industry), see Asmussen 2014; Asmussen 2016a; Asmussen 2016b; Asmussen 2016c; Asmussen 2019.

$6 \quad$ Anstey 2002; Clericuzio 1996; Debus 1977; Dym 2006; Dym 2008; Hirai 2005; Hirai-Yoshimoto 2005; Long 1991; Long 2011; Luzzini 2011; Luzzini 2013, pp. 132-137; Luzzini 2018, pp. 38, 43-44, 97-98, 120; Newman 2004; Newman 2014; Norris 2006; Norris 2007; Norris 2009; Norris 2014; Norris 2015; Norris 2016; Oldroyd 1974a; Oldroyd 1974b; Vermij 1998.

7 Agricola 1546, II, p. 413; V, p. 63; Barba 1674, pp. 70-71; Becher 1661, pp. 155-157; Boyle 1674; Boyle 1676; Cesalpino 1596, pp. 182-183; Falloppio 1564, p. 16v; Gerhard 1643, pp. 1-30; Mathesius 1562, p. 86v; Palissy 1580, pp. 197-204; Paracelsus 1894, pp. 89-113; Plattes 1639, pp. 4-7; Sherley 1672, pp. 62-69; Antonio Vallisneri, Primi itineris per Montes specimen Physico-Medicum. Archivio di Stato di Reggio Emilia, Archivio Vallisneri, 10, Scritti, minute e appunti scientifici e letterari d'Antonio Vallisneri sr., mazzo IV, pp. 44-45; Webster 1671, pp. 40-60.

8 The rehearsal of the observations and opinions of respected authorities of the past in support of a specific theory was a very common rhetorical strategy among early modern scholars in Europe, and this regardless of their different cultural or social backgrounds and of their philosophical or ideological sympathies. On this topic, see Hirai and Yoshimoto 2005; Luzzini 2013, pp. 115-117; Luzzini 2018, pp. 172-173, note 131.

9 Cito enim et sulphur, et metallica reliqua regeneratur; ut habemus apud Strabonem, qui loquens de insula Ilva (Elba nunc vulgo dicta) dicit, quod inibi effodiebatur ferrum, et sempre regenerabatur: nam si effossio intermitteretur spatio centum annorum, cum iterum illuc revertebantur fossores, reperiebant maxima ferri copiam esse regeneratam. Et non solum eo tempore, sed et nunc effoditur metallum ferreum ex eodem loco, et copiosum: ita ut Dux Florentinus maximum inde habet proventum.
} 


\section{SOUNDING THE DEPTHS OF PROVIDENCE}

\section{VAPOR}

In spite (or because) of the great variety of backgrounds and theories, it is undeniable that the organic analogy proved to be successful and pervasive in Europe throughout the early modern period and since the early Renaissance, when the theories on metallogenesis advanced by Islamic alchemists and physicians such as Geber (Jabir ibn Hayyan, 721-813), Rhazes (Muhammad ibn Zakariya al-Razi, 854-925), Avicenna (Ibn Sina, 980-1037), and by other Arabic and Persian authors (including the members of the Brethren of Purity) ${ }^{10}$ began permeating Western culture. This passage occurred chiefly through the work of Albertus Magnus (circa 1200-1280). In his De mineralibus (known in English as the "Book of Minerals": circa 1260, and first printed in 1476), he provided a synthesis of the Aristotelian theory of mineral genesis (according to which the different kinds of minerals and metals resulted from the combination and condensation of moist and dry exhalations generated underground by the solar heat $)^{11}$ and of some well-defined elements of Islamic science and alchemy. Although with different emphases, all these theories agreed in explaining the differences in the seven 'main metals' - gold, silver, copper, tin, lead, iron, and mercury, each corresponding to one of the seven classical planets - as the result of the influence of these celestial bodies on different relative proportions of two essential constituents (or 'compositional principles'): sulphur and mercury. These were considered, respectively, as the 'male' and 'female' seed on which the celestial bodies operated, thus leading to the generation of ore veins (which, in turn, were also influenced by the specific characteristics of the earth where they lay). ${ }^{12}$

During the Renaissance, the sulphur-mercury theory became widely accepted among many scholars as well as among artisans, alchemists, technicians, and a vast number of mining officials, metallurgists, and simple miners. Significantly, we can also find this concept mentioned (and presented as "the opinion of the philosophers") in the earliest printed book entirely devoted to mining activity: the Bergbüchlein ("Booklet on Mining"), published at the beginning of the sixteenth century by the German engineer and physician Ulrich Rülein von Kalbe (or von Calw, 1465-1523). ${ }^{13}$ Arguably, a main reason for the success of this notion is to be found in its versatility; in fact, this 'Aristotelian-Arabic' system of heavenly bodies influencing "the common matter of all metals" and causing the "vapors or fumes (called exhalationes minerales) of sulphur and quicksilver" to rise "from the depth of the earth" through "fissures and fractures" and to harden "into ores" (von Kalbe 1505, p. 4) ${ }^{14}$ was particularly suited to explain a large share of the natural phenomena that could be observed underground, from the more obvious to the most

The Brethren of Purity (or Brethren of Sincerity) was a religious, esoteric and philosophical society active in the Mesopotamian cities of Basra and Baghdad around the second half of the tenth century. On this topic, see ElBizri 2006; Norris 2006, p. 47; Norris 2007, p. 70. For a recent study on the transmission of alchemy from the Arab-Muslim world to the Latin West in the Middle Ages, see Moureau 2020.

11 On Aristotle's theory of mineral exhalations, see Eichholz 1949; Norris 2006, and especially pp. 44-46; Vermij 1998, and especially pp. 324-343.

12 Dym 2006; Dym 2008; Hirai 2008, pp. 3-4; Norris 2006; Norris 2007; Norris 2014; Norris 2016. It must be remarked that although "during this time, the metals lead, tin, iron, copper, mercury, silver, and gold were the commonly accepted metals, '. . ' there was some disagreement as to whether mercury should be considered a metal, as its liquidity under Earth's atmospheric conditions presented an enigma. Furthermore, during the period under consideration, there was some recognition of cobalt, zinc, and bismuth, though no general agreement as to whether they constituted true metals or not" (Norris 2014, p. 662, note 22).

13 I refer to von Kalbe 1505-and, more specifically, to the copy printed by Erhard Ratdolt and now preserved at the Bibliothèque de l'École nationale supérieure des mines de Paris (Mines ParisTech), which is considered to be one of the oldest surviving versions of this book. The English translation of all quoted passages comes from von Kalbe 1949. On the Bergbüchlein and its author, see also Norris 2006, pp. 53-55; Norris 2007, pp. 71-72; Norris 2014, pp. 40-41, 48; Dym 2008, pp. 238-239.

$14 \quad$ Sunder das Underworffen Ding oder die gemeine Materie aller Metall, ist nach der Maynung und von der Weysen, Schwefel und Quecksilber, die durch den Lauff und Einfluß des Hymels müssendt verayniget und gehertiget werden zu einem mettallischem Corper oder zu einem Ärcz. Sunder etzliche halten das durch den Lauff und Einfluß des Hymels werden aus der Tieff der Erden von Schweffel und Quecksilber aufgezogen, Dunst oder Bradem, exhalationes minerales genandt, und im Aufrauchen, in Genngen und Klufften, durch Würkung der Planeten werden verayniget und zu einem Ärcz gemachet. 
peculiar and baffling ones. Included in the latter category were the so-called Witterungen (see Figure 1): mineral fumes - or, more precisely, "rushing underground vapors of mineral origin" (Dym 2006, p. 170; Dym 2008, p. 248) - produced by ore veins in their (alleged) organic development. In being frequently associated with the sulphur-mercury theory and with the Aristotelian concept of mineral exhalations, Witterungen were, in the eyes of many early modern authors, reliable signs of the presence of ore veins. As such, in many cases these vapors became a constitutive element of the theoretical framework underlying various prospecting and dowsing practices which turned out to be quite popular among mining communities in the seventeenth and eighteenth centuries, and which owed much to the legacy of alchemical knowledge. ${ }^{15}$

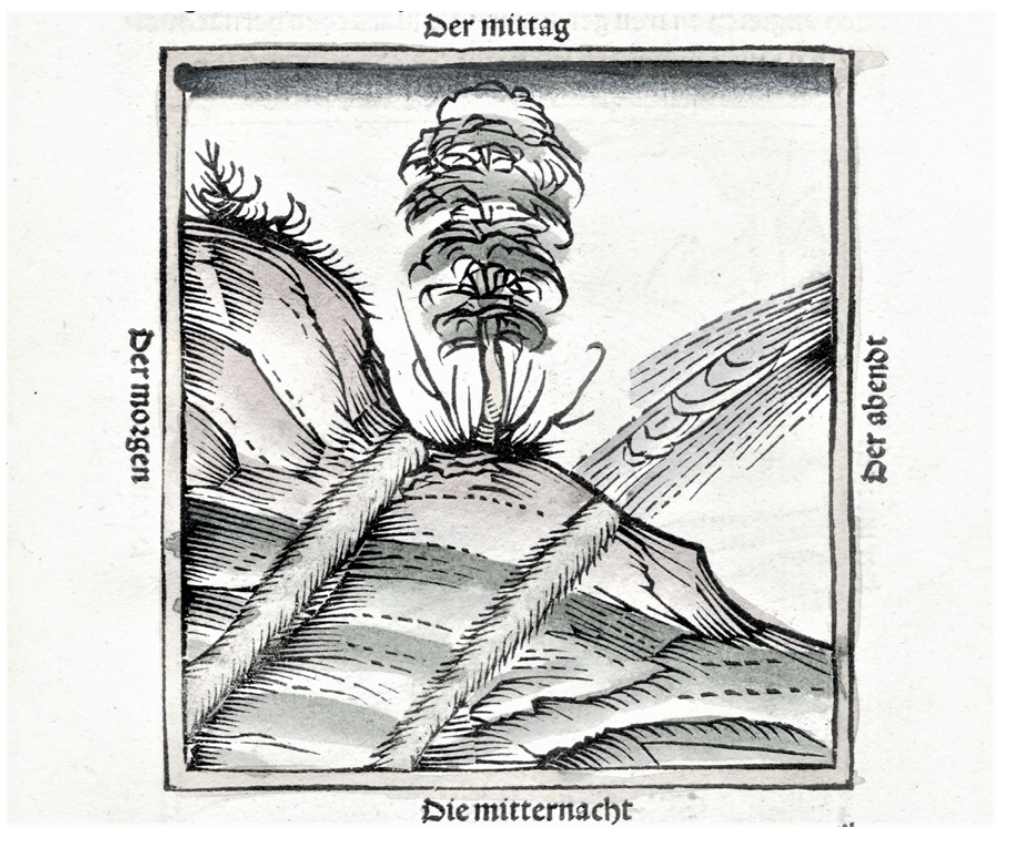

Figure 1. Ore veins (the diagonal bands) and Witterungen rushing out from them (on the right). From von Kalbe 1505. Bibliothèque de l'École nationale supérieure des mines de Paris (Mines ParisTech).

Given its countless variations and the great number of authors who (in part or exclusively) supported it, the mineral exhalation theory proved to be a remarkably flexible and successful tool for explaining the many different locations and compositions of ore veins across various European regions (Norris 2006, p. 64). ${ }^{16}$ And yet, although this interpretive model remained an important element of the debate on metal and mineral genesis well into the eighteenth century, its validity had been contested by some scholars already in the early 1500s. In his Bergbüchlein, for instance, von Kalbe observed that the sulphur-mercury system supported by many was, in fact, criticized by some who did not believe the metals "made from quicksilver," and this because metallic ores could also be found "in many locations where no quicksilver" was found (von Kalbe 1505, p.

\footnotetext{
15 On the role played by alchemical theories in the development of the mining industry and in the prospecting techniques used during the early modern period, see Dym 2008; Dym 2011. For further considerations on the nature and interpretation of Witterungen in early modern Europe, see also Dym 2006 (especially pp. 170-172); Newman 2014, p. 72.

16 As John Norris noted, "Although the properties of the known metals were commonly considered in terms of compositional Sulfur and Mercury, the supposed roles of these principles in vapour-driven metallogenesis were as varied among European authors as they had been among their Arab predecessors. Indeed, there was little unity concerning the identity of the mineral exhalations with Sulfur or Mercury, most authors postulating the vapours to correspond with one or the other of these principles, and to subsequently combine with the other in a liquid or solid form."
} 


\section{SOUNDING THE DEPTHS OF PROVIDENCE}

4). ${ }^{17}$ A similar criticism came in 1540 from the Italian metallurgist and minter Vannoccio Biringuccio (1480-circa 1539), who in his De la Pirotechnia ("On Pyrotechnics") asserted that the sulphur-mercury theory was hardly compatible with the observations he had been making through decades of experience in Italian and German mines. In fact - as he "repeated against the opinion of philosophers"- - he simply could not believe sulphur or quicksilver to be the essential constituents of all metals, he having "never seen metallic ores grow near sulphur or mercury ores". Nor was he so sure that the interaction of the two pairs of opposite qualities invoked by the sulphur-mercury theory for the formation of all metals (the hot and the cold, the dry and the wet) could actually occur, since it was difficult to imagine how these four qualities could be generated "in the same place, and in the same time" (Biringuccio 1540, p. 26r). ${ }^{18}$

\section{WATER}

Both von Kalbe and Biringuccio touched another very important point in their works - and this point, too, was grounded on a solid empirical basis. As every miner knew, the presence of water was a typical feature in mining sites. In fact—Biringuccio suggested—water seemed to be "the first and proper companion of mines, and perhaps it was even the cause of their generation"; and the wisest held it "as a universal rule, that all those mountains from whence abundant springs" originated, were "also abundant in mines" (Biringuccio 1540, Introduction). ${ }^{19}$ As the next decades would show, these 'empirical remarks' were the signs of an important conceptual change, one that led to new theories where alchemical and classical knowledge, first-hand observations, and the understanding of the role of water in the generation and growth of minerals and metals were incorporated and re-elaborated in many innovative and comprehensive interpretations.

One of the greatest champions of this novelty was Paracelsus. In his scripts (which were collected and printed in different parts and editions after his death in 1541, and became increasingly popular and influential during the next decades), he added a third ingredient (i.e. salt) to the two-principle model of the Arabic texts. According to this new interpretation, the elemental water permeating spaces and fissures in the rocks within the earth provided the primary matteror liquid matrix - from which both metals and minerals were generated, and this process resulted from the action of a vital, natural principle called Archeus. The Archeus, in turn, operated on three seminal principles through which the generative process occurred: sulphur, mercury, and salt. These, Paracelsus explained, were the so-called tria prima, and each of them was responsible for the specific characteristics of every mineral. More precisely, the "natural colors" came from salt, whereas sulphur provided the "substance and structure," and mercury the most spiritual "virtues" such as fusibility or volatility (Paracelsus 1581, p. 237). ${ }^{20}$ Therefore, the variable "degrees of refinement and relative proportions" of these immaterial, "spiritual constituens of matters" were

$17 \quad$ Noch sind etliche die halten nicht das die Metal von dem Quecksilber gewürkt werden, die weil man an vil Örttern mettalisch Ärcz hat und doch kain Quecksilber do selbs findt.

18 Quello che v'ho già detto dell'argento vivo contra a l'oppinion de li filosofi alchimici ne' la generation di metalli il medesimo vi replico di questo, perché non credo che nisun d'essi propriamente intervenga si non in sustantie simili elementali, et questo mel fa dire il veder che in nisuna cana di metallo, né anco lì appresso miniera né di solfo, né di mercurio vi si trova. Anzi pur hora sopra a ciò, et pensando m'apparisce un altro dubio da risolvere, quale è come il caldo e 'l freddo, l'humido e 'l seccho possino a ponto in un medesimo luocho in uno istante generarsi, et generati unirsi di tal forte mistione che quasi l'un si converti ne' l'altro, come dicano esser necessario che intervenga del mercurio et del solfo quando si generano li metalli. On von Kalbe's and Biringuccio's notes concerning the sulphur-mercury theory, see also Norris 2007, pp. 71-72. cagione donde le sustantie proprie de la lor generatione procedeno. Del che . . .' l'intelligenti di tali cose parlando, pigliano argumento \& danno come universal norma che tutti li monti che abondantemente scaturiscano acque sono ancor abondanti di miniere.

20 Colores autem naturales omnes proveniunt ex sale naturae, in quo consistunt, una cum balsamo rerum et coagulatione: sulphur exhibet corporum substantiam, et aedificatione; mercurius vero virtutes et arcana. See also p. 240. 
responsible for the many different qualities of the "final fruit" - that is, the different kinds of minerals and metals that could be found in nature (Norris 2007, pp. 76-80). ${ }^{21}$

As extensive studies have shown, the importance of some kind of 'compositional moisture' in the formation of metals, minerals, and stones had been acknowledged since the Hellenic period, and this view was strengthened and further elaborated by a number of Arabic and, subsequently, European scholars during the Middle Ages. However, metals and 'stony' objects were generally believed to have distinct origins, the former being understood as the result of the interaction of moist and dry exhalations, and the latter of a generative process occurring in a real aqueous medium (Alfonso-Goldfarb and Ferraz 2013, p. 31; Dym 2008, pp. 238, 247; Norris 2006, pp. 44-45, 52-53; Norris 2007, pp. 69-71; Oldroyd 1974a, pp. 145-146). Together with Agricola, Bernard Palissy, and (to a certain extent) Vannoccio Biringuccio, Paracelsus was one of the earliest authors to extend this mediating role of water to the origin of metals; an opinion that became increasingly popular and influential in its many versions during the seventeenth century, coexisting with (and, in many cases, replacing) the traditional interpretive model of mineral exhalations. ${ }^{22}$

It has been noted how these new aqueous theories - although different in many respectshad in common a "stronger empirical basis" than those "invoking only exhalations". This advantage was "rooted in the mineral industry", as the link between water and the formation of certain minerals - like vitriol, alum, saltpetre, and other kinds of salts - had been a well-known and commonly observed fact since antiquity, both in mining and in industrial practice (Norris 2007, pp. 70, 75-76, 86). ${ }^{23}$ Having witnessed phenomena such as the growth of crystals from saline solutions or the abundance of water in mines and caves, these authors aimed to make sense of their experiences (performed both underground and in laboratory) by merging them in a consistent interpretation. This 'empirical pride' shines through in writings like Agricola's De ortu et causis subterraneorum ("On the Origin and Causes of Subterranean Things") and Palissy's Discours admirables ("Admirable Discourses"), where the contempt for opinions that are "contrary to every experience" (Agricola 1546, p. 63) ${ }^{24}$ and the rhetorical contrast between "theory" and "practice" (the latter clearly representing the author's viewpoint, like in Palissy 1580 ) is a central and recurring theme.

And yet, the two factions of theorists and practitioners were all but hermetically sealed: the boundaries between direct experience and theoretical construction were as permeable as frequently and necessarily crossed, and even the work of many proud advocates of empiricism was not devoid of a strong speculative component. A good example is Agricola's theory on mineral formation. Although this interpretation was grounded on empirical evidence (Agricola had frequently observed minerals generating through an aqueous medium, like in the case of the formation of vitriol from pyrite), it was also the result of inductive reasoning. In fact, this author "extended the continuity of mineral generation even to those processes that he could not directly observe, such as the emplacement of metallic ores" (Norris 2007, p. 75). ${ }^{25}$ Similarly, Palissy's interpretive model of minerals and metals developing from 'seeds' in water solutions was

21 On this topic, see also Alfonso-Goldfarb and Ferraz 2013, p. 31; Dym 2008, pp. 244-245, 247; Hirai 2005; Hirai 2008; Oldroyd 1974a, pp. 132-136; Pagel 1958, pp. 82-88, 100-104; Pagel 1961, pp. 120-123.

22 As a matter of fact, important authors in the seventeenth century continued to uphold the mineral exhalation model. Gabriel Plattes, for example, in his book A Discovery of Subterraneall Treasure (Plattes 1639) supported this theory with successful experiments, simulating "the development of ore veins by sealing loose bituminous and sulfurous substances in a large glass retort and subjecting the whole to sustained mild heat. Finding that the material petrified into a single mass upon cooling, with mineral veins replicated by material vaporised and recondensed within the interstices, he found no reason to question the generation and mobilisation of mineral vapours by heat and their congelation by coldness" (Norris 2006, p. 59). On Plattes, see also Clericuzio 1996, pp. 293-294, 303; Debus 1961; Geoghegan 1962.

23 On this topic, see also Dym 2008, pp. 232-233; Karpenko 1992.

24 "Quo minus est ferenda vulgi opinio perridicula, poetarumque alicuius fabulae similis, et omni experimento contraria." Significantly, the Latin term "experimentum" has a dual meaning: it can be translated equally as "experience" and "experiment".

25 On Agricola, see also Hirai 2005, pp. 111-134. 


\section{SOUNDING THE DEPTHS OF PROVIDENCE}

undoubtedly the product of first-hand experiences in mining sites and in laboratories. However, it was also the result of analogies and assumptions which, in turn, had been significantly influenced by the thought of philosophers like Marsilio Ficino (1433-1499) and Girolamo Cardano (1501-1576) and, more generally, by "the intellectual revival of the Renaissance" (Hirai 2005, pp. 331-342; Oldroyd 1974a, p. 136). ${ }^{26}$

In light of these considerations we can understand why, during the early modern period, empiricism and practical knowledge continued to interact-like communicating vessels - with many different and elaborate theoretical models where alchemical concepts, philosophy, and organic analogies played an important role in the understanding of mineral generation. Nor were these analogies confined to the notion of 'seeds', but they extended to concepts such as 'soil', 'lymph', 'development', 'structure', and 'parts'. For, trees had roots, branches, and bore fruits; and so did ore veins, which were frequently described as dendritic structures (just like "subterranean trees," Norris 2007, p. 78) moving upwards, producing fruits, and undergoing a natural cycle of generation, growth, and decay (Dym 2008, p. 250).

It must be recalled here that the use of organic analogies, both botanical and animal, to describe the growth of mine ores had existed well before the filtering of "alchemical ideas '. ..' into the realm of mining through the works of Paracelsus" (Dym 2006, p. 178). Still, the increasing success of the aqueous theories during the sixteenth and seventeenth centuries and the introduction of the concept of 'seed' in the generative process of minerals and metals paved the way for a flourishing of organic analogies that contributed in shaping an enduring and influential theoretical framework for miners, technicians, practitioners and savants well into the eighteenth century. It should not surprise us, then, that similar concepts and analogies were expressed by authors from heterogeneous backgrounds, be these historical, geographical, professional, cultural, religious, or social. So, for example, the abundant presence of water in mines was to be considered a sign for the existence of ore veins not just because this opinion was confirmed by experience, but also because the connection between water and ores seemed to be satisfactorily explainable in terms of organic analogies; in fact, just like water was crucial for the growth of plants and animals from seeds, so mineral seeds needed a proper amount of water to thrive. Accordingly, water was also thought to be essential for the formation and the quality of what was described as either the "soil" for mineral seeds (Paracelsus 1581, pp. 227-228), ${ }^{27}$ or a sort of "mineral sap" (Van Helmont 1648, p. 53), ${ }^{28}$ or, more generically, a mineral matter in an undifferentiated, early, or middle stage of formation. This was the humid, muddy substance known as Gur (or Guhr, Ghur, or Bur): a viscous mixture of metallic sulphates produced by the exothermic oxidation of sulphides and associated with the weathering of rocks. ${ }^{29}$ Even the underground presence of this

26 On Palissy (and, more generally, on the - often ambiguous - rhetorical use of the contrast between theory and practice in early modern authors), see also Hirai 2005, pp. 327-349; Long 2011; Luzzini 2015, pp. 176-177; Norris 2007, pp. 80-83. On the epistemological and methodological tension between theory and practice in natural philosophy, and how this complex relationship affected science and field research during the Renaissance and the early modern period, see also Luzzini 2018, pp. 17-21; Oldroyd 1974b, pp. 303-304; Omodeo 2019. As David Oldroyd commented on the similarity between the theories advanced by Paracelsus and Palissy in spite of the different cultural background of these two authors, "That there should be such similarities in the work of a man who had little knowledge of classical culture, and probably little direct contact with the Paracelsian writings, is indicative that the notion of the growth of metals from "seeds" in an aqueous "matrix" was common currency in the sixteenth century, and that it was doubtless derived as much from the folklore of alchemy as direct influences arising from the intellectual revival of the Renaissance" (Oldroyd 1974a, p. 136).

27 Creavit Altissimus elementum aqae, ut esset velut ager in quo radices arborum mineralium ex suis seminibus ortae figerentur, ac inde truncus et rami protruderentur in terram, ut infra latius. '. .' Generationes igitur omnium mineralium ex elemento aquae protruduntur in terram, quemadmodum ex elemento terrae fructus omnes in aerem ut in terra nihil praeter ipsam radicem maneat.

28 In terra nimirum fracescens aqua, semen locale, vel insitum acquirit. Ideoque vel in liquorem (Leffas) ad omnem plantam, vel in succum (Bur) mineralem, transit, juxta species, per directionem seminum electas. On Van Helmont, see Alfonso-Goldfarb and Ferraz 2013, pp. 31-32; Pagel 1982.

29 On this topic, see Alfonso-Goldfarb and Ferraz 2013; Clericuzio 1996, p. 299; Dym 2008, pp. 242-243; Norris 2006, pp. 60-63; Norris 2007, pp. 71-85; Norris 2009, p. 38; Norris 2014; Hirai and Yoshimoto 2005, pp. 472473. An exhaustive description of the chemical components of Gur is provided in Norris 2007, p. 72, note 11; Norris 2014, pp. 42-45. 
"protometallic matter" (Norris 2014, pp. 35, 36, 40), therefore, was often believed to attest the existence of mine ores - and this in spite of the variety of origins, compositions, and functions that were ascribed to it.

\section{CHYMISTS, PHILOSOPHERS, AND DOUBTS}

Throughout the early modern period, these and other theories coexisted, overlapped, and often merged into a complex stream of knowledge whose development was shaped by balancedalthough variable - combinations of philosophical elaboration, first-hand experience in mines, experimental practice and, frequently, by a conspicuous dose of "bookish erudition" (Hirai and Yoshimoto 2005, p. 453). Such, for instance, was the case with Robert Boyle, who explained the apparent regeneration of metals in ores already exploited and exposed to the air by invoking both mineral exhalations and aqueous processes, and made frequent use of quotations from authoritative sources (such as Agricola, Mathesius, Cesalpino, Falloppio, Gerhard, Van Helmont) to support his theories (Hirai and Yoshimoto 2005). ${ }^{30}$

We find an analogous display of erudition in another proud experimentalist, Antonio Vallisneri (who was greatly influenced by Boyle's work). Although this author was - and still is - regarded as one of the greatest champions of the Galilean experimental school in Italy, such reputation did not imply for him an uncritical rejection of other theoretical and practical traditions. From Bacon's inductive science and Cartesian mechanism to Locke's empiricism and Boyle's corpuscularianism; from the rationalism of Malebranche and Leibniz's majestic theoretical system to the practical knowledge of miners, apothecaries, and technicians, a cross-pollination of theories, methods, and experiences shaped Vallisneri's research, making him equally devoted to fieldwork and theoretical interpretation and sharpening its attention to the agreement between these two essential facets of human inquiry. A voraciously curious scholar, he extended this approach also to the Earth sciences, and with quite successful results. ${ }^{31}$ Still, among the many topics in this field that drew his attention, the issue of mineral generation proved singularly problematic for him, which fact makes him a good example to examine how the experimental hurdles encountered by the organic analogy in the first decades of the eighteenth century spurred its gradual decline in favor of growing attention to "chemical processes and changes" (Oldroyd 1974b, p. 304).

Vallisneri's thoughts on this matter are clearly expressed in the Primi Itineris per Montes Specimen Physico-Medicum ("Physico-Medical Example of a First Journey through the Mountains"), a manuscript report that he wrote after a journey he made in the Northern Apennines in the summer of 1704 (see Figure 2). ${ }^{32}$ In this document, the use of organic (more specifically, vegetative) analogies in relation to minerals and metals is, literally, ubiquitous. In the gypsum and sulphur mines in Scandiano, for example, the author described ore veins as structures with "branches" stretching "downwards, like an upside-down tree" (Luzzini 2018, p. 152): ${ }^{33}$ he also saw a "tree-like piece of sulphur" with "branch-like shapes" from which "sparsely attached fruits" sucked "nourishment" and grew ripe (Luzzini 2018, p. 153). ${ }^{34}$ Other passages in the manuscript mention "crystal-like minerals" whose "nearly constant [number] of parts" seemed to prove "[the existence] of a geometric design in nature, and of a somewhat indistinct vegetative power". The

30

On Boyle's theory of mineral generation, see also Anstey 2002; Clericuzio 1990, pp. 583-585; Clericuzio 1996; Norris 2006, p. 59; Norris 2009, pp. 37-40; Oldroyd 1974a, p. 153; Principe 1998, and especially pp. 27-90; Yoshimoto 1992.

31 On Vallisneri, see Generali 2007; Generali 2008; Luzzini 2009; Luzzini 2011; Luzzini 2013; Luzzini 2015, pp. 181-185; Luzzini 2018.

32 The critical edition of this text is now published in Luzzini 2018 (all the passages from Vallisneri's Primi Itineris Specimen quoted in the paper refer to this edition).

33 Vix primum caveae fornicem ingressus observabam multi iugas sulphuris glebas flavus-pallidiusculas magnitudinis diversae, variis striis, ac ramis sulphureis intersectas deorsum versus tendentibus, inversi arboris instar . . . '

$34 \quad$ In ima fodina sulphuris truncus, quem vocant filone, residet, a quo tot veluti rami circumundique dispersi, cum pommis sparsim infixis nutrimentum sugunt, ac maturescunt. 


\section{SOUNDING THE DEPTHS OF PROVIDENCE}

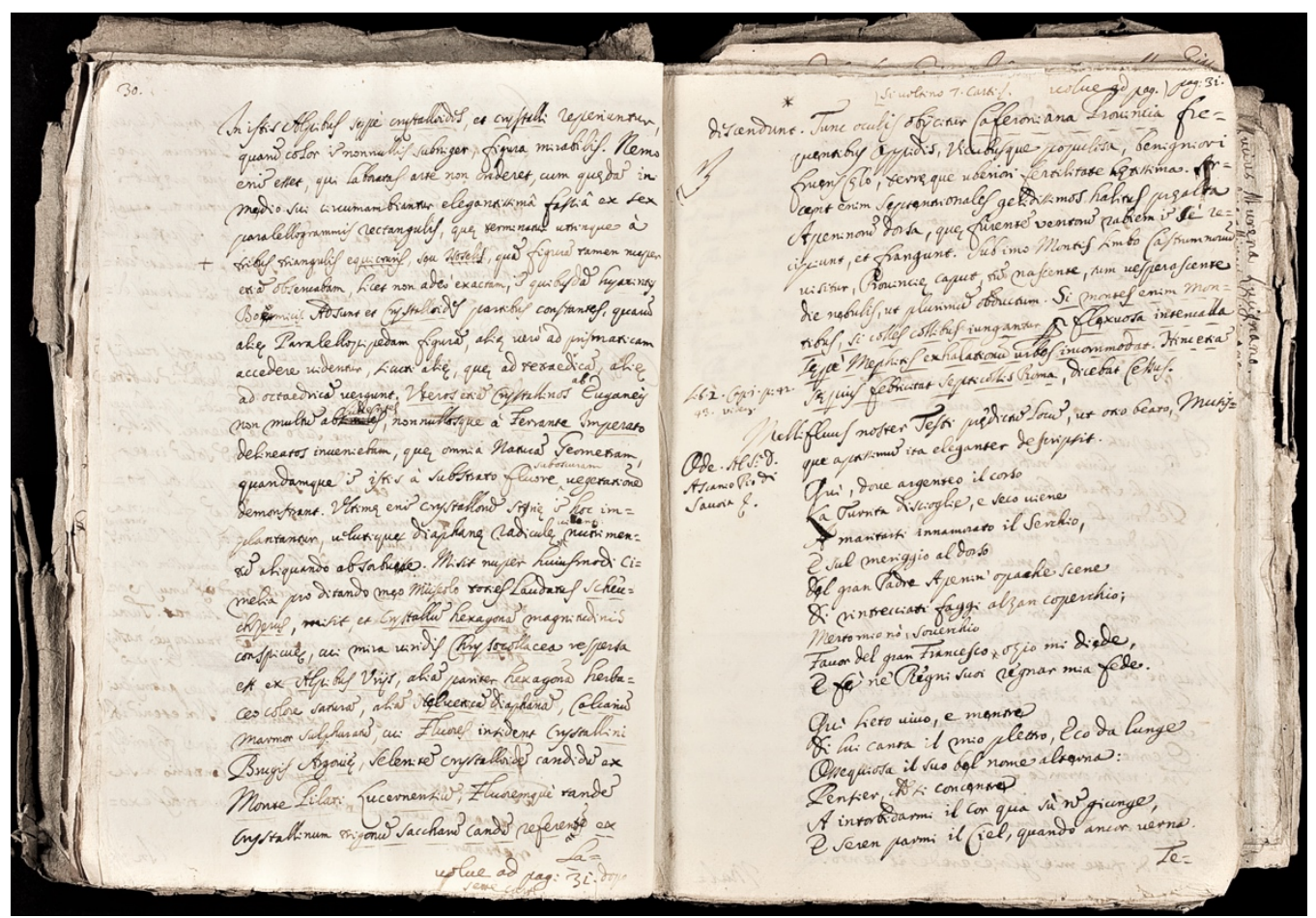

Figure 2. “. . .' all of them proving [the existence] of a geometric design in nature, and of a somewhat indistinct vegetative power in these [objects], [caused] by an exhalation from the ground." Vallisneri's manuscript Primi Itineris Specimen, p. 30 (Luzzini 2018, p. 303).

same, Vallisneri argued, could be said for the "lowest parts" of some other minerals found in the Apennines, which were "planted" in the ground and looked "like transparent little roots" (Luzzini 2018, pp. 174-175); ${ }^{35}$ or for the ore veins in the iron mines in northern Tuscany, which (he supposed) absorbed "nourishment from the rains," just like it happened "with the seeds of plants" (Luzzini 2018, p. 194). ${ }^{36}$

As Vallisneri confessed to the Swiss naturalist Louis Bourguet (1678-1742) some years later, he had quite a penchant for these analogies. In fact, supposing the existence in minerals of such organic features as seeds (or 'matrices') and nourishment allowed him to merge harmonically experimentalism with the theoretical framework of Boyle's corpuscularianism and with the Leibnizian doctrines of scala naturae and of the recognition of divine providence in creation. According to this ambitiously unifying view, therefore, it was not illogical to assume that minerals and metals ("which develop and multiply inside and outside of mines") could have "their particular seeds, or matrices," just like all the other "growing beings" (Vallisneri 2005, p. 738) ${ }^{37}$ However, this interpretation was hardly compatible with a fast-growing mass of empirical

\footnotetext{
35 Adsunt et crystalloides partibus constantes, quarum aliae paralellopipedam figuram, aliae vero ad prismaticam accedere videntur, sicuti aliae, quae ad tetraedricam, aliae ad octaedricam vergunt '. . ', quae omnia naturam geometram, quandamque in istis a substrato fluore suboscuram vegetationem demonstrant. Ultimae enim crystallorum striae in hoc implantantur, velutique diaphanae radiculae videntur nutrimentum aliquando absorbuisse.

36 A supernis enim depluentibus, nitro, salibus variis, terrae uligine impraegnatis, solaribus radiis excoctis, et luminoso illo, quod totum Orbem animat, imbutis, ebibere nutrimentum subdubito. Analogiam habemus in plantarum seminibus.

37 Veggiamo dunque che tutto quello che moltiplica e cresce ha il suo seme, o matrice, onde possiamo crederlo anche ne' minerali, che dentro e fuora delle sue miniere crescono e moltiplicano.
} 
data; and Bourguet, who was a sharp critic of what he called the "superstition of chymists" 38 (who always "want to turn the mineral kingdom into plants"), scolded his friend for wandering from experimental evidence and embracing such "vain suppositions," unsupported by "physical, and mechanical experiences". ${ }^{39}$

In his correspondence with Vallisneri, Bourguet revealed some glimpses of a theory that he would disclose a few years later in his Lettres philosophiques sur la formation des sels et des cristaux ("Philosophical Letters on the Formation of Salts and Crystals"), an essay where he marked a clear distinction between the growth of minerals and metals and the development occurring in organic bodies like animals and plants. In Bourguet's view, all these bodies were to be considered as "regular" mixtures "made up of particles of different species" (Bourguet 1729, p. 74) ${ }^{40}$ But the growth of minerals, he said, resulted from an accidental juxtaposition of new particles "from the outside," whereas the regularity of living organisms was the product of a much more complex process which entailed a coordinated "addition of new molecules within the body" (Bourguet 1729, p. 71). ${ }^{41}$

Given this distinction between the development of living and that of inanimate beings, Bourguet's interpretive model can be considered as one of the earliest applications of the organic/inorganic dichotomy to the question of mineral generation. ${ }^{42}$ As such, this theory left no room for the idea of 'mineral seed'. However, it is worth noting that both Bourguet's and Vallisneri's thoughts on this subject had been significantly influenced by Domenico Guglielmini (1655-1710) and by his corpuscularist view of crystal structure, a view that Guglielmini described in 1688 in his seminal treatise Riflessioni filosofiche dedotte dalle figure de' sali ("Philosophical Reflections derived from the Figures of Salts"). ${ }^{43}$ This work, in turn, owed much to the considerations expressed by Boyle in his Essay about the Origine and Virtues of Gems (Boyle 1672), a text where the author's sympathy for the idea of a seminal origin in minerals was far from concealed. ${ }^{44}$ Still, Bourguet's hostility for this concept was equally evident; and his opinion had no small effect on Vallisneri, whose experimental pride was far stronger than any other philosophical affection. Thus, after this epistolary discussion, Vallisneri did not seem to persist (not 'officially', at least) in advocating the thesis of a vegetative power in minerals. In any case, the hesitancy shining through in his replies to Bourguet is revealing of how pervasive the organic analogy continued to be in the first decades of the eighteenth century, even among those members of the Republic of Letters who declared their fierce opposition to alchemical and Neoplatonic knowledge.

38 Although nowadays the Italian term 'chimici' used by Bourguet refers unambiguously to chemists, I use here the word 'chymists' (as suggested by William Newman and Lawrence Principe). In fact, this word is meant to include both what we nowadays call 'chemistry' and 'alchemy', and therefore is closer to the concept intended by Bourguet in his (rather harsh) remarks. On this topic, see Newman and Principe 1998; Principe 2007. See also Hirai and Yoshimoto 2005, p. 454, note 1.

39 Pregiudizio de' chimici, che trasformar vogliono il regno minerale in vegetabile! '. . ' Ma sin a tanto che que' Signori '. . ' non avranno dimostrato, quanto in questa materia conviene, avranno la bontà di soffrire, che apogiati sopra le regole, e l'esperienze fisiche, e mecaniche, non prestiamo fede a loro vane suposizioni '. . .'. (Louis Bourguet, Letter to Antonio Vallisneri, 12 October 1721. Modena, Biblioteca Estense, Mss. It. (ms. IX. F. 11). On this epistolary debate between Vallisneri and Bourguet, see Luzzini 2011; Luzzini 2013, pp. 132-137; Luzzini 2018, pp. 97 (note 140), 175 (note 140). on Boyle's influence on Vallisneri, see also Generali 2007, pp. 59, 121-122.

$40 \quad$ La facilté avec la quelle tous les corps organisés se réduisent '. . ’’ prouve invinciblement, que ces corps, quoique si artistement composés, ne sont qu'un resultat d'un mélange régulier de particules de diverse espece.

$41 \quad$. . les unes croissent, par l'addition d'une matière qui s'agence par couches, comme en dehors, et l'accroissement se fait dans les autres, c'est-a-dire, dans celles dont la formation est parfaite '. . ', par l'addition de nouvelles molécules dans tout l'interieur à la fois.

42 On Bourguet's “organic system," see Cheung 2006; Duchesneau 2003; Duchesneau 2010; Wolfe 2019. I am thankful to the anonymous reviewer for his/her suggestions in this regard (see also the comment in note 3 ).

43 On Guglielmini's influence on Bourguet, see Hooykaas 1953. On Guglielmini's influence on Vallisneri, see Generali 2007, pp. 32, 106, 120, 121, 240-241.

44 On Boyle's influence on Guglielmini, see Generali 2007, p. 121; Sissingh 2017, pp. 53-57; Vanzo 2017. 


\section{SOUNDING THE DEPTHS OF PROVIDENCE}

\section{RELIGION, FOR EXAMPLE}

The overview provided thus far helps, I hope, to explain why in order to understand how the early modern debate on mineral (re)generation influenced the rise and development of the Earth sciences and human environmental agency we should first assess how this debate developed among different European contexts.

Such a comparative study entails significant challenges, and even a preliminary effort to define a set of reliable criteria for identifying and analyzing the most significant case studies would face important and not-so-obvious issues. What chronological boundaries should be applied? How to select different case studies so that all the main topics, forms of knowledge, and geographical area would be equally and proportionally considered? And lastly, how to avoid the risk of oversimplification as well as the opposite, but equally dangerous risk of an excessive focus on local details at the expense of the larger picture?

There are no simple answers to these questions, given the profusion of sources and contexts that need to be considered. Besides, the use of conceptual labels or boxes seems to be a particuarly ill-suited approach to the complexity of this subject. For, not only are the thematic boundaries often vague, but vagueness also extends to geographical, cultural, religious, and social contexts; to the point that some main themes of the debate contain valid elements to support different, and also mutually conflicting, historical interpretations.

Let us consider religion, for example. The typical ambivalence of Christian-or, Abrahamic - thought about nature, with its constant alternation of divine benevolence and divine wrath, offers a plausible theoretical base to support both the idea of a providentially inexhaustible and of an irreparably damaged Earth. In fact, depending on which view prevailed from time to time and from case to case (that is, the providentialist or the punitive one), the same natural phenomenon could be explained in radically different ways. Thus, the very existence of underground places where minerals and metals could generate (and, according to many, regenerate) was often seen as a clear evidence of God's generosity; in accordance with this view, two very influential authors for seventeenth century mining such as Paracelsus and the Lutheran minister Johann Mathesius (among many others, and despite their philosophical and ideological distance) ventured to describe the mineral world as the miner's "harvest" (Dym 2006, pp. 179181; Dym 2008, pp. 242-243; Norris 2009). ${ }^{45}$ In fact, just like the wheat fields ripened under the sun and - once ready - were reaped by farmers, so ore veins grew up and ripened underground, and it was up to the miners harvesting this subterranean wealth when it was neither "too early, nor too late" (Dym 2006, pp. 180-181, 184). ${ }^{46}$ Furthermore, according to Paracelsus, the mysterious Witterungen were "God-given signs of ore," and it was also possible to predict the nature and quality of the veins underground from the different colors of the sparks emitted by these vapors; white lights meant silver, tin, or lead, while red lights meant copper or iron, and yellow lights meant gold. Also, softer sparks meant richer and finer ores, whereas bright flashes revealed the presence of less perfect material (Dym 2006, p. 170; Dym 2008, p. 248).

In sharp contrast with this interpretation, some believed Witterungen to be dangerous "sources of confusion to miners," as attested by von Kalbe in his Bergbüchlein (Dym 2006, p. 170; Dym 2008, p. 248). Others, like Martin Luther (1483-1546), went so far as to consider these mysterious steams to be nothing less than the work of Satan; on the other hand, Mathesius - in one of the mining-themed sermons featured in his Sarepta - endowed Witterungen with a divine (although not necessarily benevolent) nature, and compared these fumes to the fires witnessed by

\footnotetext{
45 This concept is expressed by Mathesius in his Sarepta, and especially in the third sermon (Mathesius 1562, pp. 38-67).

46 On Mathesius - and, more generally, on the influence of a providential perspective of natural resources on the development of mining culture and on the evolution of the human-environment relationship in early modern Europe, see Alfonso-Goldfarb and Ferraz 2013, pp. 24-26; Clarke and Claydon 2010 (especially Spicer 2010); Dym 2006; Dym 2008; Norris 2009; Norris 2014; Norris 2016, pp. 664-670.
} 
the Israelites in the desert when God wanted to lead, admonish, or punish them (Dym 2006, pp. 171-172; Dym 2008, p. 248).

The concept of divine punishment was not exclusive to Mathesius. Actually, this notion was frequently invoked to explain a number of dangerous or problematic aspects of the natural world that could not be easily reconciled with a providential perspective (which, in contrast, seemed to be suggested by other evidence). A good example of this interpretive attitude is the work of another ardent supporter of the organic analogy, the German physician, chymist, and mining official Johann Friedrich Henckel (1668-1744). In his Pyritologia, Henckel-who worked in the mining district of Freiberg - suggested that the irregular distribution of ore veins in the Earth's crust was a dramatic consequence of the biblical Flood. The violence of this event, he explained, had been such as to throw the mineral kingdom "into confusion" where "parts before conjoined were separated, ores and veins dislodged, and new beds and positions given them" (Henkel 1725, pp. 300, 302). ${ }^{47}$

It is easy to see the similarities between Henckel's considerations and the influential diluvialist theories advanced a few decades earlier in England by Thomas Burnet (1635-1715), William Whiston (1667-1752), and John Woodward (1665-1728), and enthusiastically promoted on the Continent by the Swiss naturalist Johann Jakob Scheuchzer (1672-1733). Although with significant differences, all these models agreed in seeing the surface of the Earth as a wrecked, ruined version of the perfect Earth created by God at the beginning of time, an ideal environment that had been irreparably damaged by the Noachian Deluge (Burnet 1681; Whiston 1696; Woodward 1695) ${ }^{48}$ Not only was this primeval world incomparably more beautiful than the present postdiluvian ruin, it was also much more fertile, and much less hostile to life. From such premises, it was reasonable to infer that the traumatic consequences of the Flood could not leave unaffected the mineral kingdom, which-as Henckel explained in his first treatise Flora Saturnizans (Henckel 1722) — was to be considered as a subterranean counterpart of the realm of plants on the surface (see Figure 3). ${ }^{49}$ Thus, just like crops were easily struck and ruined by drought, hail, frost, and floods (as farmers knew only too well), so the 'subterranean crops' were not as fertile and regularly disposed as they used to be before the Deluge, this event having made scarcely "possible for each stratum of earth to be unmixed with any other" (Henckel 1725, p. 306). ${ }^{50}$

In short, the mineral world - similarly to the rest of nature-was a marvellous and frightening sign of God's providence and God's punishment, and both these facets of divine glory were dispensed to humanity with imponderable wisdom and relentless justice.

47 Die Historie von der Sündfluth giebt in der Natur-Lehre, insonderheit von denen obern Erd-Lagern, Höhen und Tieffen, ein solches Licht, gleich wie hinwiederum die seltsame Befindung dieser und jener Gegenden, mit ihren alda wider alles Vermuthen begrabenen Fossilien und Stücken, eine Handleitung zu denen Göttlichen Wahrheiten geben kan, als worzu uns als zum letzten Zweck alle unsere Natur-Forschung nach Pauli Erinnerung führen soll. '. . ' Sondern wir wollen uns gleich zum Mineral-Reich wenden, was alda vor Verwirrung, Trennung, Theils aber auch gantz neue Anlagen an Ertzen und Ertz-Gängen die Gewalt derer Wasser habe angerichtet. The (summarized) English translation of this passage comes from Henckel 1757, p. 64. On Henckel and his theory of mineral generation, see Dym 2008, p. 254; Dym 2011, pp. 83-86; Norris 2006, pp. 61-65; Norris 2014, p. 46; Oldroyd 1974b, pp. 278-283.

48 See, among the vast literature on this subject, Albritton 1980; Barnett 2019; Bettini 1997; Cohn 1996; Dean 1985; Luzzini 2009; Luzzini 2013, pp. 1-67, 165-226; Magruder 2006; Magruder 2008; Rappaport 1978; Rappaport 1997, pp. 57, 106-107, 109-110, 119-122, 125-128, 130-135, 154, 169, 183-187, 219, 238; Rudwick 2009; Semonin 2000, pp. 41-61; Young 1995.

49 On Henkel's Flora Saturnizans, see also Oldroyd 1974b, pp. 278-281; Sissingh 2017, pp. 75-76, 89.

$50 \quad$. . . aber auch vieles ja das meiste in ein solches Gemenge gerathen, auch bleiben lassen, daß man wohl Ursachen darhinter vermuthen kan, welche eine Erd-Art in gehörigen Lager, und anbey so gar allein und mit andern unvermenget zu sehn, so schwer und selten gestatten können, sondern meistentheils Kraut und Rüben unter einander gekommen sind. The (summarized) English translation of this passage comes from Henckel 1757, pp. 65-66. 


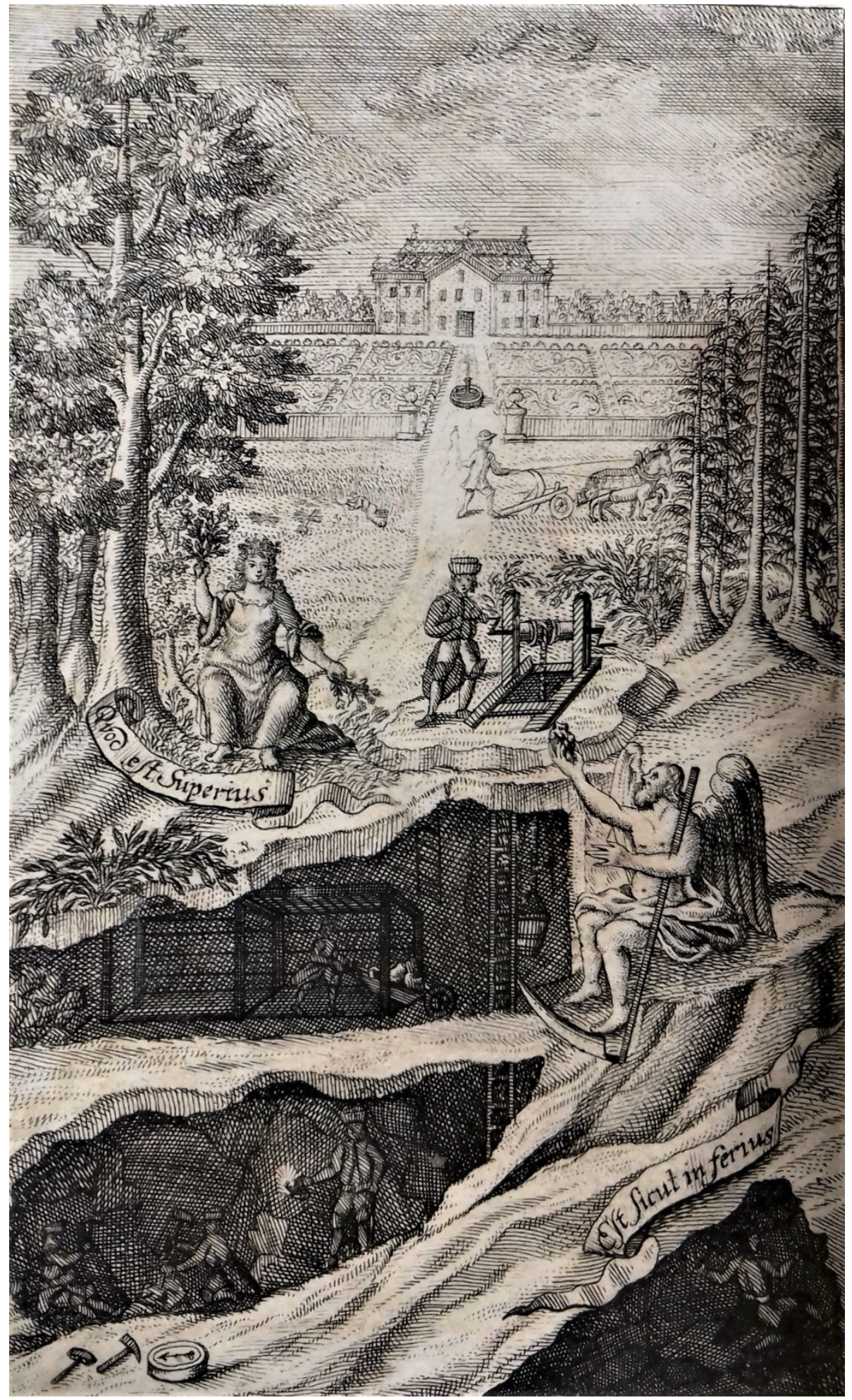

Figure 3. Quod est superius est sicut inferius ("What is above is just like what is below"), from Henckel 1722, frontispiece. Image courtesy of The History of Science Collections, University of Oklahoma Libraries. 


\section{UNEXPLORED DEPTHS}

Religion, of course, is not the only relevant — let alone the only problematic — aspect in our quest to study the debate on mineral (re)generation in early modern Europe. Other key factors demand consideration. These include the effective contribution of alchemical knowledge (which, as we have seen, remained an essential theoretical framework for both miners and savants well into the eighteenth century); the role played in this regard by different geographical and geological settings, as well as by the multitude of social and political contexts that clashed, overlapped, and intermingled incessantly all over the Continent during the early modern period; and finally, the impact that the interaction between philosophical models, empirical traditions, and emerging experimental practices had on the development of theories, technologies, and arguments.

Providing an analysis of all these issues and identifying and exploring their multiple interconnections is no simple task. There is much to discover and much to learn; for, historical reconstruction is less a matter of understanding contexts than it is of being aware of their existence, and failing to grasp the ramified implications of the early modern study of mineral generation would undermine our effort to assess how this rich body of theoretical and practical knowledge affected the development of the Earth sciences and the role of humans as geological and environmental agents. On the other hand, the very complexity of this subject is a telling evidence of its importance to us. In fact, I am persuaded that shedding new light on how our understanding of mineral generation changed through the centuries to its current form would also offer immense potential for investigating the changes that occurred in our perception of natural exploitability, renewability, and exhaustibility.

A clarification is in order here. My intention to explore this subject is based in good measure on my confidence that the history of science, like environmental history, is entitled to play a key role in the development of the ongoing environmental debate and in addressing the issue of the existence and definition of the Anthropocene: a geological and historical concept whose discussion, I believe, would be greatly enriched by a thorough investigation of its early modern roots. ${ }^{51}$ Nevertheless, I am also aware that the complexity of this subject cannot be exhaustively explored without a concrete transdisciplinary and interdisciplinary effort - as doing history of science means acquiring and using scientific knowledge at least as much as doing science means recognizing its profoundly historical nature. Thus, in order to carry out this research work successfully, it will be necessary to adopt a method that goes beyond the (however indispensable) study of sources and theories to embrace field research and experimental replication as customary practices. ${ }^{52}$ In accordance with this view, I intend in future to combine an in-depth analysis of the sources that influenced the early modern debate on mineral generation and a confrontation with the existing literature on the subject with a third methodological tool, a set of experimental activities. These will include the replication in laboratory of significant mineral processes, of alchemical/experimental practices, and the comparative exploration of historical mining sites in Europe (such as the quicksilver mines of Almadén in Spain, the iron mines of Fornovolasco and of Elba Island, the copper mines of Agordo in Italy, the Wieliczka salt mines in Poland, the copper, lead, and iron mines of Rammelsberg and Goslar in Germany, the silver mines of Jáchymov in Czech Republic, the copper and lead mines of Rammelsberg in Germany, the transnational Erzgebirge area, and other sites that will be identified as the research proceeds).

In combining the study of early modern science, mining, and alchemy with environmental history, I hope to contribute towards a more historically contextualized and more pragmatic approach to the current discussion on the Anthropocene. Also, I hope to make a methodological

On this topic, see, for example, Barton and Miglietti 2015; Gould and Usher 2020; Miglietti and Morgan 2017; Renn 2020a; Renn 2020b.

52 On the experimental history of science and on its importance to historical research, see Fors, Principe and Sibum 2016; Luzzini 2007; Luzzini 2011; Luzzini 2013, pp. 100-101, 124-129; Luzzini 2015; Luzzini 2018, pp. 29 50, 53, 120, 195; Newman and Principe 2002; Rampling 2014; Rampling 2016; Sibum 2000. 


\section{SOUNDING THE DEPTHS OF PROVIDENCE}

contribution in promoting scientific knowledge, experimental replication, and field research as essential elements of historical inquiry, thus helping to remove the epistemological and methodological obstacles that still hinder the dialogue between the natural sciences and the humanities (especially, but not exclusively, with respect to the environmental debate).

As it usually happens when embarking on complex interdisciplinary projects, the final result is all but predictable. It might support our initial assumptions or it might question them, or even prove them wrong. In any case, the work I have performed so far-although preliminaryhas convinced me that I have just begun to scratch the surface of a deep and fertile vein.

\section{ACKNOWLEDGEMENTS}

I wish to express my heartfelt thanks to the History of Science Collections and to the Department of the History of Science at the University of Oklahoma for funding this work with a generous 2020 Andrew W. Mellon Fellowship. I am deeply grateful to the staff, graduate students, and faculty (Kerry Magruder, Hunter Heyck, Kraig Bartel, James Burnes, Tara Carlisle, Cassondra Darling, Sam Fellows, Margaret Gaida, Stella Graves Stuart, Piers Hale, Younes Mahdavi, Suzanne Moon, JoAnn Palmeri, Kristen M. Raffa, Melissa Rickman, Karen Rupp-Serrano, Peter Soppelsa, Ken Taylor, Rienk Vermij, Stephen P. Weldon, and many other friends) who inspired and supported me along the way. I am also much indebted to Rienk Vermij and to the anonymous reviewer for devoting their time and scholarly competence to improve the quality of this paper with precious comments and suggestions.

\section{ARCHIVES}

Bourguet, Louis. Letter to Antonio Vallisneri, 12 October 1721. Modena, Biblioteca Estense, Mss. It. (ms. IX. F. 11).

Vallisneri, Antonio. Primi itineris per Montes specimen Physico-Medicum. Archivio di Stato di Reggio Emilia, Archivio Vallisneri, 10, Scritti, minute e appunti scientifici e letterari d'Antonio Vallisneri sr., mazzo IV.

\section{REFERENCES}

Agricola, Georgius (Bauer, Georg). 1546. De ortu et causis subterraneorum lib. V. Basileae: Per Hieronimymum Frobenium et Nic. Episcopum.

Albertus Magnus. 1476. Alberti Magni philosophorum maximi de mineralibus liber. Patavium: Petrus Maufer.

Albritton, Claude. 1980. The Abyss of Time: Changing Conceptions of the Earth's Antiquity after the Sixteenth Century. San Francisco: Freeman Cooper.

Alfonso-Goldfarb, Anamaria and Ferraz, Marcia H. M. 2013. Gur, ghur, guhr or bur? The quest for a metalliferous prime matter in early modern times. The British Journal for the History of Science 46(1): 23-37.

Anstey, Peter. 2002. Boyle on Seminal Principles. Studies in the History and Philosophy of Biology 33: 597630.

Asmussen, Tina. 2014. Subterranean economies: Resource flows and metal culture in early modern mining, 1490-1630. Research Project. Max Planck Institute for the History of Science (https://www.mpiwgberlin.mpg.de/research/projects/FGDupre_Asmussen_Material-and-Epistemic-Cultures).

Asmussen, Tina. 2016a. Glück auf! Fortuna und risiko im frühneuzeitlichen Bergbau. FKW // Zeitschrift für Geschlechterforschung und visuelle Kultur 60: 30-41.

Asmussen, Tina. 2016b. Mountain clamor! Resource flows and metal culture in early modern mining. Research Project. Max Planck Institute for the History of Science (https://www.mpiwgberlin.mpg.de/content/mountain-clamor-resource-flows-and-metal-culture-early-modern-mining).

Asmussen, Tina. 2016c. The Kux as a site of mediation: Economic practices and material desires in the early modern German mining industry. In: Sites of Mediation: Connected Histories of Places, Processes, and Objects in Europe and Beyond, 1450-1650, edited by Susanna Burghartz, Lucas Burkart and Christine Göttler, 159-182. Leiden: Brill. 
Asmussen, Tina. 2019. Wild men in Braunschweig: Economies of hope and fear in early modern mining. Renaissance Studies Special Issue: Cultural and Material Worlds of Mining in Early Modern Europe (2019, early view online).

Barba, Alvaro Alonso. 1674. The Art of Metals in which is declared the Manner of their Generation and the Concomitants of them..., written in Spanish by Albaro Alonso Barba..., translated in the Year 1669 by the R. H. Edward, Earl of Sandwich. London: Printed for S. Mearne.

Barba, Alvaro Alonso. 1729. Arte de los metales: en que se enseña el verdadero beneficio de los de oro, y plata por azogue, el modo de fundirlos todos, y como se han de refinar, y apartar unos de otros. Nuevamente aora añadido. Madrid: En la Imprenta de Bernardo Peralta.

Barnett, Lydia. 2019. After the Flood: Imagining the Global Environment in Early Modern Europe. Baltimore: Johns Hopkins University Press.

Barton, William M., and Miglietti, Barbara. 2015. An eighteenth-century thought experiment on climate change: Johann Jakob Scheuchzer's De ignis seu caloris certa portione Heluetiae adsignata (1708). Lias 42(2): 135-166.

Becher, Johann Joachim. 1661. Natur-Kündigung der Metallen. Frankfurt: In Verlegung Johan Wilhelm Ammons und Wilhelm Serlins.

Bettini, Amalia. 1997. Cosmo e Apocalisse: Teorie del Millennio e storia della Terra nell'Inghilterra del Seicento. Florence: Olschki.

Biringuccio, Vannoccio. 1540. De la pirotechnia. Venezia: Per Curzio Navò et Fratelli, al Segno del Lion.

Bourguet, Louis. 1729. Lettres philosophiques sur la formation des sels et des cristaux et sur la generation \& les mechanisme organique des plantes et des animaux. Amsterdam: Chez Francois l'Honore.

Boyle, Robert. 1672. An Essay about the Origine and Virtues of Gems. London: Printed by William Godbid.

Boyle, Robert. 1674. Observations about the Growth of Metals in their Ore Exposed to the Air. London: Printed by William Godbid.

Boyle, Robert. 1676. Observationes de generatione metallorum in minera sua aeri expositorum. Londini: Typis Gulielmi Godbid, Impensis Mosis Pitt, Ad insigne Angeli in Coemeterio D. Pauli.

Burnet, Thomas. 1681. Telluris theoria sacra: orbis nostri originem et mutationes generales, quas aut iam subiit, aut olim subiturus est, complectens. Londini: Typis R. N. Impensis Gualt. Kettilby, ad Insigne Capitis Episcopi in Coemeterio Paulino.

Cesalpino, Andrea. 1596. De Metallicis Libri Tres. Romae: Ex Typographia Aloysii Zannetti.

Cheung, Tobias. 2006. The hidden order of preformation: Plans, functions, and hierarchies in the organic systems of Louis Bourguet, Charles Bonnet and Georges Cuvier. Early Science and Medicine 11(1): $11-49$.

Clericuzio, Antonio. 1990. A redefinition of Boyle's chemistry and corpuscular philosophy. Annals of Science 47: 561-589.

Clericuzio, Antonio. 1996. Alchimie, philosophie corpusculaire et minéralogie dans la Metallographia de John Webster. Revue d'histoire des sciences 49(2-3): 287-304.

Cohn, Norman. 1996. Noah's Flood: The Genesis Story in Western Thought. New Haven and London: Yale University Press.

Dean, Dennis R. 1985. The rise and fall of the Deluge. Journal of Geological Education 33(2): 84-93.

Debus, Allen G. 1961. Gabriel Plattes and his chemical theory of the formation of the Earth's crust. Ambix 9 (3): $162-165$.

Debus, Allen G. 1977. The Chemical Philosophy: Paracelsian Science and Medicine in the Sixteenth and Seventeenth Centuries. Mineola (NY): Dover Publications.

Demartin, Francesco, Campostrini, Italo, Ferretti, Paolo, and Rocchetti, Ivano. 2018. Fiemmeite $\mathrm{Cu}_{2}\left(\mathrm{C}_{2} \mathrm{O}_{4}\right)(\mathrm{OH})_{2} \cdot 2 \mathrm{H}_{2} \mathrm{O}$, a new mineral from Val di Fiemme, Trentino, Italy. Minerals 8(6): 248.

Duchesneau, François. 2003. Louis Bourguet et le modèle des corps organiques. In: Antonio Vallisneri. L'edizione del testo scientifico d'età moderna, edited by Maria Teresa Monti, 3-31. Florence: Olschki.

Duchesneau, François. 2010. Louis Bourguet and the model of organic bodies. In: The Rationalists: Between Tradition and Innovation, edited by Carlos Fraenkel, Dario Perinetti, and Justin E.H. Smith, 77-98. Dordrecht: Springer.

Dym, Warren Alexander. 2006. Mineral fumes and mining spirits: Popular beliefs in the Sarepta of Johann Mathesius (1504-1565). Reformation \& Renaissance Review 8(2): 161-185.

Dym, Warren Alexander. 2008. Alchemy and mining: Metallogenesis and prospecting in early mining books. Ambix 55(3): 232-254.

Dym, Warren Alexander. 2011. Divining Science: Treasure Hunting and Earth Science in Early Modern Germany. Leiden and Boston: Brill. 


\section{SOUNDING THE DEPTHS OF PROVIDENCE}

Eichholz, David E. 1949. Aristotle's theory of the formation of metals and minerals. Classical Quarterly 43(3/4): 141-146.

El-Bizri, Nader. 2006. Brethren of Purity. In: Medieval Islamic Civilization: An Encyclopedia, edited by Josef W. Meri, Volume 1, 118-119. New York-London: Routledge.

Falloppio, Gabriele. 1564. De medicatis aquis, atque de fossilibus tractatus pulcherrimus, ac maxime utilis. Venetiis: Apud Ludovicum Avantium.

Fors, Hjalmar, Principe, Lawrence M., and Sibum, H. Otto. 2016. From the library to the laboratory and back again: Experiment as a tool for historians of science. Ambix 63(2): 85-97.

Generali, Dario. 2007. Antonio Vallisneri. Gli anni della formazione e le prime ricerche. Florence: Olschki.

Generali, Dario (editor). 2008. Antonio Vallisneri. La figura, il contesto, le immagini storiografiche. Florence: Olschki.

Geoghegan, D. 1962. Gabriel Plattes' caveat for alchymists. Ambix 10(2): 97-102.

Gerhard, Johann. 1643. Decas quaestionum physico-chymicarum de metallis. Typis Philiberti Brunnii.

Gould, Pauline, and Usher, Phillip John (editors). 2020. Early Modern Écologies: Beyond English Ecocriticism. Amsterdam: Amsterdam University Press.

Guglielmini, Domenico. 1688. Riflessioni filosofiche dedotte dalle figure de' sali. Bologna: Per gli Eredi d'Antonio Pisarri.

Henckel, Johann Friedrich. 1722. Flora Saturnizans, die Verwandschaft des Pflanzen mit dem Mineralreich. Leipzig: Verlegts Johann Christian Martini.

Henckel, Johann Friedrich. 1725. Pyritologia, Oder: Kieß-Historie, Als des vornehmsten Minerals. Leipzig: Verlegts Johann Christian Martini.

Henckel, Johann Friedrich. 1757. Pyritologia: Or, a History of the Pyrites, the Principal Body of the Mineral Kingdom. London: Printed for A. Millar and A. Linde.

Hirai, Hiro. 2005. Le concept de semence dans les théories de la matière à la Renaissance. De Marsile Ficin à Pierre Gassendi. Thournout: Brepols.

Hirai, Hiro. 2008. Logoi Spermatikoi and the concept of seeds in the mineralogy and cosmogony of Paracelsus. Revue d'histoire des sciences 61(2): 1-21.

Hirai, Hiro, and Yoshimoto, Hideyuki. 2005. Anatomizing the sceptical chymist: Robert Boyle and the secret of his early sources on the growth of metals. Early Science and Medicine 10(4): 453-477.

Hooykaas, Reyer. 1953. Domenico Guglielmini et le développement de la cristallographie. Atti della Fondazione Giorgio Ronchi 7(1): 13-28.

Kalbe (von), Ulrich. 1505. Das Bergbüchlein. Augsburg: Erhard Ratdolt.

Kalbe (von), Ulrich. 1949. Bergwerk- und Probierbüchlein. Translated and edited by A. G. Sisco and C. S. Smith. New York: AIME Press.

Karpenko, Vladimír. 1992. The chemistry and metallurgy of transmutation. Ambix 39(2): 47-62.

Long, Pamela O. 1991. The openness of knowledge: An ideal and its context in 16th-century writings on mining and metallurgy. Technology and Culture 32(2): 318-355.

Long, Pamela O. 2011. Artisans/Practitioners and the Rise of the New Sciences, 1400-1600. Corvallis (OR): Oregon State University Press.

Luzzini, Francesco. 2007. Antonio Vallisneri e la questione dei vermicelli spermatici: un'indagine storiconaturalistica. In: Antonio Vallisneri. La figura, il contesto, le immagini storiografiche, edited by Dario Generali, 73-89. Florence: Olschki.

Luzzini, Francesco. 2009. Flood conceptions in Vallisneri's thought. In: Geology and Religion: A History of Harmony and Hostility, edited by Martina Kölbl-Ebert, 77-81. London: Geological Society.

Luzzini, Francesco. 2011. Matrices, not seeds. Vallisneri's research on mines: Between empiricism and philosophy. In: History of Research in Mineral Resources, edited by J. E. Ortiz, O. Puche, I. Rábano and L. F. Mazadiego, 105-112. Madrid: Instituto Geológico y Minero de España.

Luzzini, Francesco. 2013. Il miracolo inutile: Antonio Vallisneri e le scienze della Terra in Europa tra XVII e XVIII secolo. Florence: Olschki.

Luzzini, Francesco. 2015. Through dark and mysterious paths. Early modern science and the search for the origin of springs from the 16th to the 18th centuries. Earth Sciences History 34(2): 169-189.

Luzzini, Francesco. 2018. Theory, Practice, and Nature In-between. Antonio Vallisneri's Primi Itineris Specimen. Berlin: Edition Open Access/Max Planck Institute for the History of Science.

Magruder, Kerry V. 2006. Global visions and the establishment of theories of the Earth. Centaurus 48(4): 234-257.

Magruder, Kerry V. 2008. Thomas Burnet, Biblical idiom, and $17^{\text {th }}$ century theories of the Earth. In: Nature and Scripture in the Abrahamic Religions: Up to 1700, edited by Jitse M. Van der Meer and Scott Mandelbrote, Volume 2, 451-490. Leiden: Brill. 


\section{FRANCESCO LUZZINI}

Mathesius, Johann. 1562. Sarepta oder Bergpostill, sampt der Jochimssthalischen kurtzen Chroniken. Nuremberg: Gedrückt zu Nürnberg durch Johann von Berg.

Morgan, John, and Miglietti, Barbara (editors). 2017. Governing the Environment in the Early Modern World: Theory and Practice. London: Routledge.

Moureau, Sébastien. 2020. Min al-Kīmiyā' ad Alchimiam. The transmission of alchemy from the ArabMuslim world to the Latin West in the Middle Ages. Micrologus 28: 87-141.

Newman, William R. 2004. Promethean Ambitions: Alchemy and the Quest to Perfect Nature. Chicago: University of Chicago Press.

Newman, William R. 2014. Robert Boyle, transmutation, and the history of chemistry before Lavoisier: A response to Kuhn. Osiris 29(1): 63-77.

Newman, William R., and Principe, Lawrence M. 1998. Alchemy vs. chemistry: The etymological origins of a historiographic mistake. Early Science and Medicine 3(1): 32-65.

Newman, William R., and Principe, Lawrence M. 2002. Alchemy Tried in the Fire: Starkey, Boyle, and the Fate of Helmontian Chymistry. Chicago: University of Chicago Press.

Norris, John A. 2006. The mineral exhalation theory of metallogenesis in pre-modern mineral science. Ambix 53(1): 43-65.

Norris, John A. 2007. Early theories of aqueous metallogenesis in the sixteenth century. Ambix 54(1): 6986.

Norris, John A. 2009. The providence of mineral generation in the sermons of Johann Mathesius (15041565). In: Geology and Religion: A History of Harmony and Hostility, edited by Martina KölblEbert, 37-40. London: Geological Society.

Norris, John A. 2014. Johann Mathesius and sulfur-mercurius in the silver mines of Joachimstal. Osiris 29(1): 35-48.

Norris, John A. 2015. Agricola's Bermannus: A dialogue of mineralogical humanism and empiricism in the mines of Jáchymov. In: Latin Alchemical Literature of Czech Provenance, edited by Tomáš Nejeschleba and Jiří Michalík, 7-20. Olomouc: Palacký University.

Norris, John A. 2016. Mining and metallogenesis in Bohemia during the sixteenth century. In: Alchemy and Rudolf II: Exploring the Secrets of Nature in Central Europe in the $16^{\text {th }}$ and $17^{\text {th }}$ Centuries, edited by Ivo Purš and Vladimír Karpenko. Prague: Artefactum.

Oldroyd, David R. 1974a. Some Neo-Platonic and Stoic influences on mineralogy in the sixteenth and seventeenth centuries. Ambix 21: 128-156.

Oldroyd, David R. 1974b. Some phlogistic mineralogical schemes, illustrative of the evolution of the concept of 'Earth' in the 17th and 18th centuries. Annals of Science 31: 269-305.

Omodeo, Pietro D. 2019. Practices and theories of contingency in Renaissance approaches to nature. In: Contingency and Natural Order in Early Modern Science, edited by Pietro Daniel Omodeo and Rodolfo Garau, 93-114. Cham: Springer.

Pagel, Walter. 1958. Paracelsus: An Introduction to Philosophical Medicine in the Era of the Renaissance. Basel-New York: Karger.

Pagel, Walter. 1961. The prime matter of Paracelsus. Ambix 9: 117-135.

Pagel, Walter. 1982. Joan Baptista van Helmont, Reformer of Science and Medicine. Cambridge: Cambridge University Press.

Palissy, Bernard. 1580. Discours admirables de la nature des eaux et fonteines. Paris: Chez M. le Ieune, a l'enseigne du serpent, devant le college de Cambray.

Paracelsus (von Hohenheim, Philippus Aureolus Theophrastus Bombastus). 1581. Congeries Paracelsicae Chemiae de Transmutationibus Metallorum, ex Omnibus quae de His ab Ipso scripta reperire licuit hactenus. Accessit Genealogia Mineralium, atque Metallorum Omnium, eiusdem Autoris. Francofurti: Apud Andream Wechelum.

Paracelsus (von Hohenheim, Philippus Aureolus Theophrastus Bombastus). 1894. The Hermetic and Alchemical Writings of Paracelsus. Volume 1. Edited and translated by Arthur Edward Waite. London: James Elliott and Co., Temple Chambers, Falcon Court, Fleet Street, E.C.

Plattes, Gabriel. 1639. A Discovery of Subterraneall Treasure. London: By I. Okes, for Iasper Emery.

Principe, Lawrence M. 1998. The Aspiring Adept: Robert Boyle and his Alchemical Quest. Princeton: Princeton University Press.

Principe, Lawrence M. (editor). 2007. Chymists and Chymistry: Studies in the History of Alchemy and Early Modern Chemistry. New York: Science History Publications.

Rampling, Jennifer. 2014. Transmuting sericon: Alchemy as "Practical Exegesis" in early modern England. Osiris 29(1): 19-34. 


\section{SOUNDING THE DEPTHS OF PROVIDENCE}

Rampling, Jennifer. 2016. English alchemy before Newton: An experimental history. Circumscribere 18(1): $1-11$.

Rappaport, Rhoda. 1978. Geology and orthodoxy: The case of Noah's Flood in eighteenth-century thought. The British Journal for the History of Science 11(1): 1-18.

Rappaport, Rhoda. 1997. When Geologists Were Historians, 1665-1760. Ithaca, NY: Cornell University Press.

Renn, Jürgen. 2020a. The Anthropocene and the history of science. In: The Anthropocenic Turn: The Interplay between Disciplinary and Interdisciplinary Responses to a New Age, edited by Gabriele Dürbeck and Philip Hüpkes, 37-58. New York: Routledge.

Renn, Jürgen. 2020b. The Evolution of Knowledge: Rethinking Science for the Anthropocene. Princeton: Princeton University Press.

Rudwick, Martin J. S. 2009. Biblical Flood and geological deluge: The amicable dissociation of geology and Genesis. In: Geology and Religion: A History of Harmony and Hostility, edited by Martina KölblEbert, 103-110. London: Geological Society.

Semonin, Paul. 2000. American Monster: How the Nation's First Prehistoric Creature became a Symbol of National Identity. New York-London: New York University Press.

Sherley, Thomas. 1672. A Philosophical Essay declaring the Probable Causes, whence Stones are produced in the Greater World. London: Printed for William Cademan, at the Pope's Head, in the Lower Walk of the New-Exchange.

Sibum, H. Otto. 2000. Experimental history of science. In: Museums of Modern Science: Nobel Symposium 112, edited by Svante Lindqvist, 77-86. Canton (MD): Science History Publications.

Sissingh, Wim. 2017. Deposits of Earth Science: Printing History of Early Modern Geology 1455-1800. Utrecht: Utrecht University.

Spicer, Andrew. 2010. "God hath put such secretes in nature": The Reformed Kirk, Church-Building and the Religious Landscape in Early Modern Scotland. In: God's Bounty? The Church and the Natural World, edited by Peter Clarke and Tony Claydon, 260-265. Boydell: Woodbridge.

Vallisneri, Antonio. 2005. Epistolario (1714-1729). Edited by Dario Generali. Florence: Olschki.

Van Helmont, Jan Baptist. 1648. Ortus medicinae. Amsterodami: Apud Ludovicum Elzevirum.

Vanzo, Alberto. 2017. Corpuscularism and experimental philosophy in Domenico Guglielmini's Reflections on Salts. In: The Idea of Principles in Early Modern Thought, edited by Peter A. Anstley, 147-171. New York: Routledge.

Vermij, Rienk. 1998. Subterranean fire: Changing theories of the Earth during the Renaissance. Early Science and Medicine 3(4): 323-347.

Webster, John. 1671. Metallographia, or, a History of Metals. London: Printed for A. C. for Walter Kettilby.

Whiston, William. 1696. A New Theory of the Earth, from its original, to the consummation of all things. London: Printed by R. Roberts, for Benj. Tooke.

Wolfe, Charles T. 2019. Life as concept and as science in early modern thought. In: Encyclopedia of Early Modern Philosophy and the Sciences, edited by Dana Jalobenau and Charles T. Wolfe, 1-16. Dordrecht: Springer.

Woodward, John. 1695. An Essay toward a Natural History of the Earth. London: Printed for Richard Wilkin.

Yoshimoto, Hideyuki. 1992. Chemical studies of young Boyle: Their Helmontian phase and the Seminal Principles. Kagakushi 19: 233-246.

Young, Davis A. 1995. The Biblical Flood: A Case Study of the Church's Response to Extrabiblical Evidence. Grand Rapids: William B. Eerdmans Publishing Company; Carlisle: The Paternoster Press. 